\title{
УДК: 636.09:637.12:579.864
}

ВИГОВСЬКА Л.М., канд. вет. наук., ст. наук. сп. e-mail: lnvygovska@gmail.com Національний університет біоресурсів і природокористування Украӥни, Украӥнська лабораторія якості і безпеки продукиії АПК

\section{ВИВЧЕННЯ БІОЛОГІЧНИХ ВЛАСТИВОСТЕЙ ЕПІЗООТИЧНИХ ШТАМІВ SALMONELLA SPP}

\begin{abstract}
Актуальність токсикоінфекиій, щяо викликаються Salmonella spp., дуже висока у всьому світі. Захворювання характеризується різними клінічними проявами. Можливо безсимптомне носійство $i$ важкі випадки септичних форм. Потирення стійких до антимікробних препаратів атипових варіантів значно ускладнюе терапію та диференційну діагностику за сальмонельозу. В статті наведені результати досліджень біологічних властивостей (культурально-морфологічних, ферментативних, патогенних, антибіотикорезистентності) итамів SALMONELLA SPP, виділених на території України при проведенні мікробіологічних досліджень .
\end{abstract}

чутливість.

Ключові слова: сальмонельоз, біологічні властивості, антибіотикорезистентність,

Вступ. Рід Salmonella - грамонегативні рухомі загинулички родини Enterobacteriaceae, види: S. enterica и $S$. bongori. Найбільш патогенними для людини $(>99.5 \%)$ є підвиди S. enterica (Salmonella enterica enteritidis та Salmonella enterica typhimurium). Етіотропна терапія за сальмонельозу полягає у застосуванні похідних пеніциліну і фторхінолонів $[1,2,3]$. Проте, за даними Всесвітньої організації охорони здоров'я, ефективність антимікробних препаратів має тенденцію до зниження через поширення серед мікроорганізмів феномену антибіотикорезистентності [4]. Першочерговою умовою виникнення антибіотикорезистентних популяцій мікроорганізмів $\epsilon$ безконтрольне застосування антимікробних препаратів у гуманній та ветеринарній медицині; у тваринництві - як стимулятори росту; у рослинництві - як засоби боротьби і профілактики хвороб рослин; у харчовій промисловості - при консервуванні різних харчових продуктів, виловленої риби та свіжого м'яса, виробництві вина, пива, квасу і так далі $[5,6,7]$. Нині значної актуальності набуває питання про безпеку тваринницької продукції та відповідності складу діючої речовини в лікарських засобах $[8,9,10,11]$. Світові міжнародні організації у 2015 р. (МЕБ-ФАО-ВООЗ) прийняли Глобальний план взаємодії стосовно контролю за антимбіотикорезистентністю $[12,13]$. Виділено наступні етапи: спільні дії по боротьбі 3 АМР; гарантування ефективності антимікробних препаратів; сприяння завбачливому та відповідальному застосуванню антибіотиків.

Мета роботи - вивчення біологічних властивостей та чутливості до антибіотиків епізоотичних штамів Salmonella spp. в $S$-, $R$-, $L$ - формах.

Матеріали і методи досліджень. Вивчали біологічні властивості Salmonella spp. сероваріантів $S$. cholerae suis, $S$. typhimurium, $S$. dublin, $S$. enteritidis, $S$. gallinarum за культурально-морфологічними, ферментативними, антигенними властивостями, патогенністю(вірулентність для білих мишей) та чутливістю до антибіотиків. Антигенну структуру культур визначали в РА на склі 3 сироватками сальмонельозними О-комплексними i монорецепторними О- і Н-аглютинуючими виробництва компанії SIFIN, Germany. Властивості культур вивчали в $S$-, $R$-, $L$ - формах сферопластного типу (колонії типу В). Чутливість культур до антибіотиків вивчали дискодифузіальним методом відповідно до Методичних вказівок "Визначення чутливості мікроорганізмів до антибактеріальних препаратів» MO3 України, 2007 [14], використовуючи диски виробництва компанії HiMedia з мінімальними інгібуючими 
дозами препаратів. Інтерпритацію результатів проводили відповідно до рекомендацій EUCAST ((European Committee on Antimicrobial Susceptibility Testing).

Результати досліджень та їх обговорення. Культури були виділені при проведенні мікробіологічних досліджень матеріалу з господарств Київської, Вінницької областей. При дослідженні матеріалу було виділено: від загиблих курей (16 зразків) 5 штамів $S$. gallinarum, 4 штами S. typhimurium; клінічно здорових курчат (16 зразків) - 7 штамів S. pullorum; загиблих курчат (20 зразків) - 20 штамів S. gallinarum; яйця курячі шкаралупи (9 зразків) - 3 штами S. pullorum; від клінічно здорових та хворих свиней (100 зразків) - 10 штамів S. cholerae suis; телят (50 зразків) - 5 штамів $S$. dublin та 5 штамів $S$. enteritidis. Досліджені культури грамнегативні палички розміром 2-4 × 0,5-0,8 мкм; у деяких культур $(S$. cholerae suis с, S. typhimurium b) в полі зору, зустрічалися овальні, коковидні, видовжені форми бактерій. Культури $S$. cholerae suis d, S. cholerae suis e, S. typhimurium d, $S$. dublin с в мазках мали вигляд, переважно, грамнегативних структур, проте в полі зору зустрічалися поодинокі грампозитивні структури та різної величини вакуолізовані кулясті структури. Рухливість культур визначали у препараті «роздавлена крапля». Завдяки перетрихіально розташованих джгутикам сальмонели рухомі, за виключенням культур S.gallinarum-pullorum (табл. 1).

Таблиия 1

\section{Культурально-морфологічні особливості Salmonella $(\mathrm{n}=5)$}

\begin{tabular}{|c|c|c|c|c|c|c|}
\hline Культури & $\begin{array}{c}\text { Фарбування } \\
\text { за Грамом }\end{array}$ & $\begin{array}{c}\text { Рухли } \\
\text { вість }\end{array}$ & $\begin{array}{c}\text { Форма } \\
\text { колоній }\end{array}$ & $\begin{array}{c}\text { Діаметр } \\
\text { колоній (мм) }\end{array}$ & $\begin{array}{c}\text { Рівень дисоціації } \\
\text { колоній на МПА } \\
\text { (R -форми), \% }\end{array}$ & $\begin{array}{c}\text { Дисоціація ку- } \\
\text { льтури в пробі } \\
\text { кип'ятиня }\end{array}$ \\
\hline 1 & 2 & 3 & 4 & 5 & 6 & 7 \\
\hline S.cholerae suis a & $\overline{\Gamma-}$ & + & $\mathrm{S}$ & $1-2$ & 5 & - \\
\hline S.cholerae suis b & $\Gamma$-* & + & $\mathrm{S}$ & 2 & 5 & $-*$ \\
\hline S.cholerae suis c & $\begin{array}{c}\text { гетероморфні } \\
\text { структури }\end{array}$ & + & $\mathrm{R}$ & до 3 & 100 & $+* *$ \\
\hline S.cholerae suis $d$ & $\begin{array}{c}\text { гетероморфні } \\
\text { структури }\end{array}$ & + & L (B) & до 0.5 мм & - & - \\
\hline S.cholerae suis e & $\begin{array}{c}\text { гетероморфні } \\
\text { структури }\end{array}$ & + & L (B) & до 0,5 мм & - & - \\
\hline S.typhimurium a & $\Gamma-$ & + & $\mathrm{S}$ & до 3 & 5 & - \\
\hline S.typhimurium b & $\begin{array}{c}\text { гетероморфні } \\
\text { структури }\end{array}$ & + & $\mathrm{R}$ & до 4 & 100 & $+* *$ \\
\hline S.typhimurium c & $\Gamma-$ & + & $S$ & $2-3$ & 5 & - \\
\hline S.typhimurium d & $\begin{array}{c}\text { гетероморфні } \\
\text { структури }\end{array}$ & + & $\mathrm{L}(\mathrm{B})$ & до 1 мм & - & - \\
\hline S.dublin $a$ & $\Gamma-$ & + & $\mathrm{S}$ & $2,5-3$ & 5 & - \\
\hline S.dublin b & $\Gamma-$ & + & $\mathrm{S}$ & $2,5-3$ & 5 & - \\
\hline S.dublin c & $\begin{array}{c}\text { гетероморфні } \\
\text { структури }\end{array}$ & + & L(B) & до 1 мм & - & - \\
\hline S.enteritidis a & $\Gamma-$ & + & $\mathrm{S}$ & 3 & 5 & - \\
\hline S.enteritidis $b$ & $\Gamma-$ & + & $\mathrm{S}$ & 3 & 5 & - \\
\hline S.enteritidis c & $\Gamma-$ & + & $\mathrm{S}$ & 3 & 5 & - \\
\hline S. gallinarum a & $\overline{\Gamma-}$ & - & $S$ & 3 & 5 & - \\
\hline S. gallinarum b & $\Gamma-$ & - & $\mathrm{S}$ & 2,8 & 5 & - \\
\hline S. gallinarum c & $\Gamma-$ & - & $\mathrm{S}$ & $3-4$ & 5 & - \\
\hline
\end{tabular}

Примітки: * Г- -грамнегативні палички; ** + -наявність дисоцііації (значний осад у вигляді пластівців, який не розбивається при струшуванні). 
На МПБ добові культури утворювали рівномірну каламуть 3 невеликою кількістю білого аморфного осаду, що легко розбивався при струшуванні. Культури серогрупи D ( $S$. dublin a, b; S. enteritidis a, b, c, d; S. gallinarum a,b,c) утворювали пристінне кільце. На МПА культури утворювали колонії переважно S - форми, від 1-3 до 2,5-4 мм в діаметрі, прозорі, ніжні, сіруватого кольору; на середовищі Ендо росли у вигляді ледь рожевих прозорих колоній, колір середовища не змінювався. Дисоціюючі культури $S$. cholerae suis с, S. typhimurium b утворювали в МПБ велику кількість білого аморфного осаду, на щільних середовищах добові культури росли у вигляді колоній R-форми.

Культури S. cholerae suis d, S. cholerae suis e, S. typhimurium d, S. dublin с в рідких середовищах після 24 годин культивування утворювали слабке помутніння; на щільних середовищах - дуже дрібні колонії; при перегляді під мікроскопом (об'єктив х10) колонії зазначених культур мали не дрібнозернисту, характерну для бактеріальних колоній, а мереживну структуру. Розміри колоній варіювали від 0,1 до 1 мм в діаметрі.

Культури S.cholerae suis (a, b, c, d, e,) ферментували глюкозу, маніт, мальтозу, арабінозу, сорбіт і ксилозу з утворенням кислоти й газу, не утворювали сірководень, не відновлювали нітрати; ферментативні властивості у культур S.cholerae suis c, d, е проявлялися iз затримкою, що проявлялося повільним та слабким кислото- та газо- утворенням. S.typhimurium (a,b,c,d) ферментували з утворенням кислоти і газу глюкозу, арабінозу, маніт, мальтозу, сорбіт і дульцит; редукували нітрати в нітрити, виділяли сірководень. У культур S.typhimurium b, d ферментація цукрів відбувалася повільно, зі слабким газоутворенням та утворенням кислоти на низькому рівні. S. dublin (a,b,c) зброджували з утворенням кислоти і газу: глюкозу, маніт, мальтозу, сорбит, редукували нітрати в нітрити, виділяли сірководень. Культура $S$. dublin с відрізнялася низьким рівнем ферментативної активності. S. enteritidis $(\mathrm{a}, \mathrm{b}, \mathrm{s})$ ферментували глюкозу, маніт, ксилозу, рамнозу, дульцит, виділяли сірководень, редукували нітрати в нітрити. Культури S. gallinarum $(\mathrm{a}, \mathrm{b}, \mathrm{c})$ ферментували глюкозу, маніт, повільно ферментували ксилозу, дульцит, рамнозу, редукували нітрати в нітрити, виділяли сірководень. Всі досліджені культури не ферментували лактозу і цукрозу, не утворювали індол і сечовину. На вісмут-сульфіт агарі культури (крім культур S. cholerae suis) утворювали чорні колонії s-форми 3 металевим блиском. Ферментативні властивості культур відповідали видовим та серогрупрвим ознакам, культури в R- формі відрізнялися затримкою сахаролітичних реакцій та інших ферментативних властивостей. У культур в L- формі рівень активності був мінімальним, із значною затримкою, штами $S$. typhimurium та $S$. dublin втратили здатність утворювати сірководень та редукувати нітрати у нітрити.

Таблиия 2

Визначення антигенної структури Salmonella $(\mathrm{n}=\mathbf{5})$

\begin{tabular}{|c|c|c|c|c|c|c|c|}
\hline \multirow{2}{*}{ Штами } & \multirow{2}{*}{ 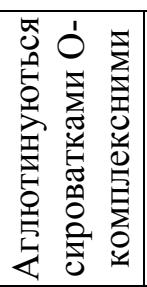 } & \multirow{2}{*}{ 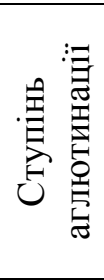 } & \multirow{2}{*}{ 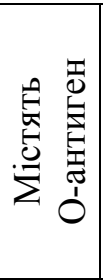 } & \multirow{2}{*}{ 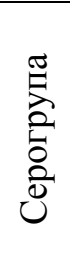 } & \multirow{2}{*}{ 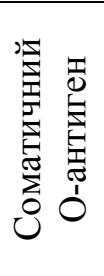 } & \multicolumn{2}{|c|}{ Джгутиковий Н-антиген } \\
\hline & & & & & & Фаза 1 & Фаза 2 \\
\hline 1 & 2 & 3 & 4 & 5 & 6 & 7 & 8 \\
\hline S. cholerae suis a & 1,3 & +++++ & O 7 & $\mathrm{C} 1$ & 6,7 & $c+++$ & $1,2,5,6+++$ \\
\hline S. cholerae suis b & 1,3 & +++ & $\mathrm{O} 7$ & $\mathrm{C} 1$ & 6,7 & $c+++$ & $1,2,5,6+++$ \\
\hline S. cholerae suis c & 1,3 & ++ & $\mathrm{O} 7$ & $\mathrm{C} 1$ & 6,7 & $c++$ & $1,2,5,6+$ \\
\hline S. cholerae suis $\mathrm{d}$ & 1,3 & ++ & $\mathrm{O} 7$ & $\mathrm{C} 1$ & 6,7 & $c++$ & $1,2,5,6+$ \\
\hline S. cholerae suis e & 1,3 & ++ & $\mathrm{O} 7$ & $\mathrm{C} 1$ & 6,7 & $c++$ & $1,2,5,6+$ \\
\hline S. cholerae suis $\mathrm{f}$ & 1,3 & +++ & $\mathrm{O} 7$ & $\mathrm{C} 1$ & 6,7 & $c+++$ & $1,2,5,6+++$ \\
\hline
\end{tabular}


Продовження таблищі 2

\begin{tabular}{|c|c|c|c|c|c|c|c|}
\hline 1 & 2 & 3 & 4 & 5 & 6 & 7 & 8 \\
\hline S. cholerae suis h & 1,3 & ++++ & O 7 & $\mathrm{C} 1$ & 6,7 & $c+++$ & $1,2,5,6+++$ \\
\hline S. typhimurium a & 1,2 & ++++ & $\mathrm{O} 4$ & B & $1,4,(5), 12$ & $i++++$ & $\begin{array}{c}1,2,5,6++++ \\
2++++; 5++++\end{array}$ \\
\hline S. typhimurium b & 1,2 & ++ & $\mathrm{O} 4$ & $\mathrm{~B}$ & $1,4,(5), 12$ & $I++$ & $2+; 5+$ \\
\hline S. typhimurium c & 1,2 & ++++ & O 4 & B & $1,4,(5), 12$ & $I++++$ & $\begin{array}{c}1,2,5,6++++; \\
2++++; 5++++\end{array}$ \\
\hline S. typhimurium $\mathrm{d}$ & 1,2 & ++ & $\mathrm{O} 4$ & $\mathrm{~B}$ & $1,4,(5), 12$ & $i++$ & $2+; 5+$ \\
\hline S. dublin a & 1,5 & ++++ & O 9 & D1 & $1,9,12,(\mathrm{Vi})$ & $g++++; p++++$ & - \\
\hline S. dublin b & 1,5 & ++++ & O 9 & D1 & $1,9,12,(\mathrm{Vi})$ & $\mathrm{g}++++; \mathrm{p}+++$ & - \\
\hline S. dublin c & 1,5 & ++ & O 9 & D1 & $1,9,12,(\mathrm{Vi})$ & $\mathrm{g}++; \mathrm{p}++$ & - \\
\hline S. enteritidis a & 1,5 & ++++ & O 9 & D1 & $1,9,12$ & $g+++; m++++$ & $1,2,5,6+++$ \\
\hline S. enteritidis b & 1,5 & ++++ & O 9 & D1 & $1,9,12$ & $g++++; m+++$ & $1,2,5,6++++$ \\
\hline S. enteritidis c & 1,5 & ++++ & O 9 & D1 & $1,9,12$ & $g++++; m++++$ & $1,2,5,6+++$ \\
\hline S. gallinarum a & 1,5 & ++++ & O 9 & D1 & $1,9,12$ & - & - \\
\hline S. gallinarum b & 1,5 & ++++ & O 9 & D1 & $1,9,12$ & - & - \\
\hline S. gallinarum c & 1,5 & +++ & O 9 & D1 & $1,9,12$ & - & - \\
\hline
\end{tabular}

Антигенна структура досліджених культур відповідала типовим ознакам; культури в $\mathrm{R}$-формі не аглютинувалися O- і Н- аглютинуючими сироватками; L-форми S. cholerae suis (d, e), S. typhimurium (d), S. Dublin (c) не втратили аглютинуючої здатності, проте рівень аглютинації був значно нижчим, ніж у культур в S-формі.

Таблиця 3

Результати визначення патогенності для білих мишей штамів Salmonella $(\mathbf{M} \pm \mathbf{m}, \mathbf{n}=\mathbf{2 0})$

\begin{tabular}{|c|c|c|c|c|c|c|c|c|c|c|c|c|c|}
\hline \multirow{2}{*}{$\begin{array}{l}\text { Доза } \\
\text { Зараження } \\
\text { КУО/см }\end{array}$} & \multirow{2}{*}{$\begin{array}{l}\text { Дослідні } \\
\text { тварини }\end{array}$} & \multicolumn{12}{|c|}{ Штами Salmonella } \\
\hline & & 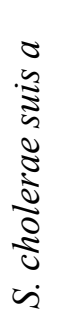 & 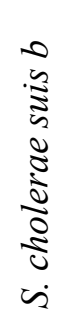 & 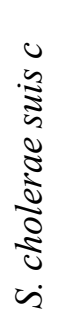 & 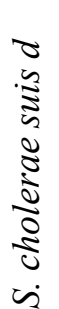 & 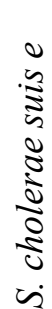 & 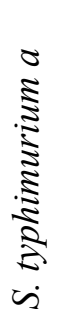 & 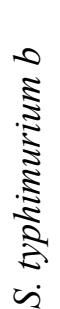 & 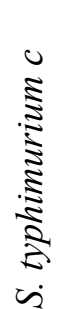 & 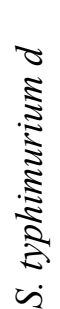 & 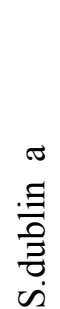 & 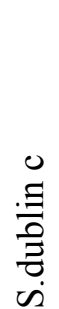 & 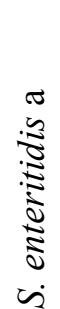 \\
\hline $1,0 \times 10^{10}$ & Загинули & 20 & 20 & 8 & 2 & 2 & 20 & 7 & 20 & 4 & 20 & 4 & 20 \\
\hline $1,0 \times 10^{9}$ & Загинули & 11 & 10 & 1 & 0 & 0 & 14 & 2 & 16 & 1 & 17 & 2 & 17 \\
\hline $1,0 \times 10^{8}$ & Загинули & 9 & 7 & 0 & 0 & 0 & 11 & 0 & 10 & 0 & 12 & 0 & 13 \\
\hline $1,0 \times 10^{7}$ & Загинули & 3 & 2 & 0 & 0 & 0 & 4 & 0 & 3 & 0 & 5 & 0 & 5 \\
\hline $1,0 \times 10^{6}$ & Загинули & 1 & 0 & 0 & 0 & 0 & 2 & 0 & 1 & 0 & 2 & 0 & 1 \\
\hline $1,0 \times 10^{5}$ & Загинули & 0 & 0 & 0 & 0 & 0 & 0 & 0 & 0 & 0 & 0 & 0 & 0 \\
\hline $1,0 \times 10^{4}$ & Загинули & 0 & 0 & 0 & 0 & 0 & 0 & 0 & 0 & 0 & 0 & 0 & 0 \\
\hline $1,0 \times 10^{3}$ & Загинули & 0 & 0 & 0 & 0 & 0 & 0 & 0 & 0 & 0 & 0 & 0 & 0 \\
\hline $1,0 \times 10^{2}$ & Загинули & 0 & 0 & 0 & 0 & 0 & 0 & 0 & 0 & 0 & 0 & 0 & 0 \\
\hline
\end{tabular}

Підшкірне введення мишам культур $S$. cholerae suis, S. typhimurium, S.dublin, S. enteritidis у дозах $1,0 \times 10^{10} \mathrm{KУO} / \mathrm{cm}^{3}$ викликало загибель $100 \%$ дослідних тварин. Зараження тварин культурами R-форми ( $S$. cholerae suis $c$, S. typhimurium b), у дозах $1,0 \times 10^{10} \mathrm{KУO} / \mathrm{cm}^{3}$ викликало загибель лише 40 \% тварин (S. cholerae suis c) та $35 \%$ (S. typhimurium $b$ ) тварин 
відповідно. Зараження тварин культурами, що знаходяться в стані L-форм, в дозах 1,0×10 10 КУО/см ${ }^{3}$ викликало загибель $10 \%$ (S. cholerae suis $d$, e) та 20\% (S. typhimurium $d$, S.dublin c) відповідно.

Зараження тварин культурами $S$. cholerae suis a та $S$. cholerae suis $b$ в дозах $1,0 \times 10^{9}$

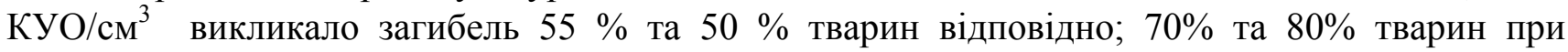
зараженні штамами $S$. typhimurium a та S. typhimurium c відповідно; 75\% - при зараженні тварин культурами S.dublin $a$ та S. enteritidis $a$. Зараження тварин культурами в стані Rдисоціації в дозах $1,0 \times 10^{9} \mathrm{KУO} / \mathrm{cm}^{3}$ викликало загибель $5 \%$ та $10 \%$ тварин при зараженні штамами $S$. cholerae suis $c$ та $S$. typhimurium $b$ відповідно. Введення тваринам культурам, що знаходяться в стані L-форм, в дозах $1,0 \times 10^{9} \mathrm{KVO} / \mathrm{cm}^{3}$ не викликало загибелі тварин, заражених штамами $S$. cholerae suis $d$, e; викликало загибель 5\% тварин, заражених штамом $S$. typhimurium d, та $10 \%$ - S.dublin с відповідно.

Зараження тварин культурами в стані R- L -дисоціації в більш низьких концентраціях

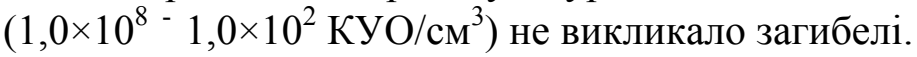

Введення тваринам культур $S$. cholerae suis a та $S$. cholerae suis $b$ в дозах $1,0 \times 10^{7}$ КУО/см ${ }^{3}$ викликало загибель $15 \%$ та $10 \%$ мишей відповідно; введення культур S. typhimurium a та S. typhimurium c в таких дозах викликало загибель $20 \%$ та $15 \%$ тварин відповідно; введення в зазначеній дозі культур S.dublin a та S. enteritidis a викликало загибель $25 \%$ мишей.

Зараження тварин культурою $S$. cholerae suis a в дозі $1,0 \times 10^{6} \mathrm{KУO} / \mathrm{cm}^{3}$ викликало загибель 5\% мишей; зараження тварин культурою S. cholerae suis $b$ в такій дозі загибелі мишей не викликало. Серед тварин, заражених культурами $S$. typhimurium a та S. dublin a в дозах $1,0 \times 10^{6} \mathrm{KУO} / \mathrm{cm}^{3}$ загинуло $10 \%$ мишей; заражених культурами $S$. Typhimurium $c$ та S. enteritidis $a-5 \%$. Отже, культури в стані дисоціації поступово втрачають патогенні властивості.

Таблиия 4

Результати досліджень чутливості Salmonella spp. до антибіотиків (n=5)

\begin{tabular}{|c|c|c|c|c|c|}
\hline $\begin{array}{c}\text { Група } \\
\text { антибіотиків }\end{array}$ & $\begin{array}{l}\text { S. cholerae } \\
\text { suis }\end{array}$ & S. typhimurium & S.dublin & S. enteritidis & Примітка \\
\hline 1 & 2 & 3 & 4 & 5 & 6 \\
\hline Penicillins & $\mathrm{H} / \mathrm{Y}$ & $\mathrm{\Psi}, \mathrm{H} / \mathrm{\Psi}$ & $\mathrm{H} / \mathrm{\Psi}, \mathrm{M} / \mathrm{\Psi}$ & $\mathrm{H} / \mathrm{\Psi}, \mathrm{M} / \mathrm{\Psi}$ & \\
\hline Cephalosporins & Н/ч, М/Ч, ч & ч, В/ч, М/ч & $\mathbf{M} / \mathrm{Y}, \mathrm{H} / \mathrm{Y}$ & М/ч, Н/ч, & $\begin{array}{c}100 \% \text { чутливі до } \\
\text { Cefotaxime }\end{array}$ \\
\hline Carbapenems & $B / 4$ & $\mathrm{~B} / \mathrm{\Psi}$ & $\mathrm{B} / \mathrm{Y}$ & 4 & $100 \%$ чутливі \\
\hline Aminoglycosides & $\mathrm{H} / \mathrm{\Psi}, \mathrm{M} / \mathrm{\Psi}$ & $\begin{array}{c}\text { в/ч, м/ч } \\
\text { (sreptomycin) }\end{array}$ & $\mathrm{H} / \mathrm{ч}, \mathrm{\Psi}($ sizomicin $)$ & $\mathrm{H} / \mathrm{\Psi}, \mathrm{M} / \mathrm{\Psi}$ & \\
\hline Macrolides & $\mathrm{H} / \mathrm{Y}$ & $\mathrm{H} / \mathrm{Y}$ & \multicolumn{2}{|c|}{ н/ч, ч(Azithromycin) } & \\
\hline Lynkozamides & $\mathrm{H} / \mathrm{\Psi}$ & $\mathrm{H} / \mathrm{Y}$ & \multicolumn{2}{|c|}{ н/ч, м/ч (Clindamycin) } & \\
\hline Tetracycline & $\mathrm{H} / \mathrm{Y}$ & $\mathrm{H} / \mathrm{ч}$ & $\mathrm{H} / \mathrm{\Psi}$ & $\mathrm{H} / \mathrm{Y}$ & $100 \%$ не чутливі \\
\hline Fluoroquinolones & $\begin{array}{c}\mathrm{ч}, \\
\mathrm{H} / \mathrm{\Psi}(\text { floxacin }) \\
\end{array}$ & В/ч & \multicolumn{2}{|c|}{$\mathrm{H} / \mathrm{\iota}, \mathrm{u}($ floxacin $)$} & \\
\hline Nitrofuran & $\mathrm{H} / \mathrm{\Psi}, \mathrm{M} / \mathrm{\Psi}$ & $\mathrm{H} / \mathrm{Y}$ & $\mathrm{H} / \mathrm{u}, \mathrm{M} / \mathrm{u}($ Fuzidin $)$ & $\mathrm{H} / \mathrm{u}, \mathrm{M} / \mathrm{\Psi}$ & \\
\hline Asolo & $\mathrm{H} / \mathrm{\Psi}$ & $\mathrm{H} / \mathrm{Y}$ & $\mathrm{H} / \mathrm{Y}$ & $\mathrm{H} / \mathrm{Y}$ & $100 \%$ не чутливі \\
\hline Amphotericin B & $\mathrm{H} / \mathrm{Y}$ & $\mathrm{H} / \mathrm{Y}$ & $\mathrm{H} / \mathrm{Y}$ & $\mathrm{H} / \mathrm{Y}$ & $100 \%$ не чутливі \\
\hline Chloramphenicol & $\mathrm{H} / \mathrm{u}, \mathrm{M} / \mathrm{\Psi}$ & $\mathrm{H} / \mathrm{Y}$ & 4 & $\mathrm{~B} / \mathrm{\Psi}$ & \\
\hline Vancomycin & M/ч & $\mathrm{M} / \mathrm{\Psi}$ & $\mathrm{M} / \mathrm{\Psi}$ & М/ч & $\begin{array}{c}100 \% \\
\text { малочутливі }\end{array}$ \\
\hline Rifampicin & $B / 4$ & $\mathrm{H} / \mathrm{Y}$ & $\mathrm{H} / \mathrm{Y}$ & $\mathrm{M} / \mathrm{Y}$ & \\
\hline Polimixin B & $\mathrm{H} / \mathrm{Y}$ & $\mathrm{B} / \mathrm{\Psi}$ & $\mathrm{M} / \mathrm{Y}$ & $\mathrm{M} / \mathrm{Y}$ & \\
\hline
\end{tabular}

Примітка: в/ч-високочутливі; ч-чутливі; м/ч-малочутливі; н/ч-нечутливі. 
Штами S. cholerae suis до пеніцілінів проявляли резистентність або малу чутливість. Культури в R- та L-формі були малочутливими та чутливими, тобто чутливість штамів підвищувалася. Штами S. typhimurium були не чутливі до бензилпеніциліну, чутливі до піперациліну та ампіциліну. Культури в R- та L-формі виявилися більш резистентними до даних антибіотиків. Штами S. dublin в S-формі були малочутливі до бензилпеніциліну, нечутливі до піперациліну та ампіциліну; в L-формі - малочутливі до бензилпеніциліну та чутливі до піперациліну та ампіциліну. Штами S. enteritidis - малочутливі до бензилпеніциліну, не чутливі до піперациліну та ампіциліну. До цефалоспоринів штами S. cholerae suis малочутливі, чутливі, до цефазоліну та цфуроксиму не чутливі; культури в R- та L-формі виявилися, за деякими виключеннями, чутливими та високочутливими. Штами S. typhimurium в S-формі - чутливі або високочутливі; в R- та L-формі - малочутливі або чутливі. Штами $S$. dublin в S-формі резистентні або малочутливі до більшості антибіотиків даної групи; до цефотаксиму - чутливі; в L-формі, в основному, чутливі, до окремих антибіотиків малочутливі. Штами S. enteritidis - не чутливі, малочутливі, до цефотаксиму - чутливі.

До аміноглікозідів штами $S$. cholerae suis в $S$-формі - резистентні та малочутливі; в Rта L-формі - в основному малочутливі та чутливі. S. typhimurium в S-формі чутливі та високочутливі; в R- та L-формі відмічається підвищення резистентності культур - малочутливі та чутливі. Штами $S$. dublin в S-форм і до аміноглікозідів не чутливі (за виключенням сізоміцину); в L-формі - чутливі. Штами S. enteritidis - не чутливі та малочутливі.

До макролідів та лінкозамідів $S$. cholerae suis та $S$. Typhimurium в $S$-, $R$ - та $L$-формі в основному не чутливі; $S$. dublin, $S$. enteritidis малочутливі, значної різниці між чутливістю штамів за дисоціації та в $S$ - формі не відмічається.

До тетрациклінів $S$. cholerae suis в S-формі не чутливі, в $R$ - та $L$ - формі - малочутливі. $S$. typhimurium в $S$-, $R$ - та $L$-формi в основному малочутливі; $S$. dublin - в S-формі резистентні, в $L$-формі - малочутливі та чутливі. $S$. enteritidis не чутливі.

До фторхінолонів $S$. cholerae suis в $\mathrm{S}$-формі малочутливі та чутливі; в $R$ - та $L$-формi відмічається значне підвищення чутливості культур (чутливі та високочутливі). S. typhimurium в $S$-формі до фторхінолонів високочутливі, в $R$ - та $L$-формі відбувається значне підвищення резистентності культур - вони чутливі, в деяких випадках - малочутливі. S. dublin в S-формі резистентні або малочутливі, в $L$-формі підвищується чутливість культур - вони чутливі та високочутливі. S. enteritidis до різних препаратів не чутливі/ малочутливі/ чутливі.

До майже всіх препаратів нітрофуранів досліджені культури виявилися малочутливими; культура $S$. cholerae suis в L -формі проявляла резистентність; S. dublin в L -формі виявилася більш чутливою. До азолів досліджувані культури проявляли резистентність, в окремих випадках - малу чутливість. До карбопенемів досліджені культури в S-формі були високочутливими, культури в $R$ - та $L$-формі виявилися дещо більш резистентними. До амфотерицину В вивчаемі культури проявляли, в основному, резистентність. До левоміцетину та ванкоміцину - малу чутливість, деякі культури - резистентність та чутливість. До piфампіцину $S$. cholerae suis в $\mathrm{S}$-формі - високочутливі, в $R$ - та $L$-формі - не чутливі, S. typhimurium, $S$. dublin, $S$. enteritidis - не чутливі та малочутливi в $S$-, $R$ - та $L$-формі. До поліміксину - $S$. cholerae suis в S- $R$ - та $L$ формі - не чутливі; $S$. typhimurium в S- формі високочутливі; S. dublin в S-формі -малочутливі, в L -формі - не чутливі; S. enteritidis малочутливі.

\section{Висновки та перспективи подальших досліджень}

1. Досліджені штами Salmonella spp. В S-формі мали типові культурально-морфологічні, ферментативні та патогенні властивості, антигенну структуру. Штами в R- та L- фор- 
мах відрізнялися від штамів в S-формі низьким рівнем біологічної активності та втратою деяких властивостей

2. Штами Salmonella spp. проявляли резистентність до більшості антибіотиків 3 досліджених груп; в більшості випадків спостерігалися ознаки дисоціації культур при взаємодії з антибактеріальними засобами, що проявлялося стимуляцією росту культури навколо диску з антибіотиком, суцільним ростом резистентних колоній в проміжках зон інгібіції.

3. В станах дисоціації відбувалися певні зміни в чутливості культур до антибіотиків. До пеніцілінів, цефалоспоринів, аміноглікозідів, фтрохінолонів спостерігалося підвищення чутливості у штамів S. cholerae suis, S.dublin; у S. typhimurium - зниження чутливості. У всіх культур в $R$-, $L$ - формах значно знижувалася чутливість до карбопенемів. До макролідів та лінкозамідів змін у чутливості не реєстрували. Підвищувалася чутливість культур до тетрациклінів, за виключенням $S$. typhimurium в R- формі. Нітрофурани - відмічали зниження чутливості S. ch.suis L- форми та підвищення - у S. dublin $L$ - форми. До азолів відмічали зниження $S$. ch.suis в $R$ - формі, інши культури -без змін. До амфотерііціну В - зниження майже у всіх культур, в окремих $S$. ch.suis- підвищення. До ріфампіцину та полимиксину зниження у більшості культур.

\section{СПИСОК ЛІТЕРАТУРИ}

1. Салманов А.Г. Антибіотикорезистентність в хірургії: Монографія [Текст] / А. Г. Салманов, В. Ф. Марієвський, В. В. Бойко [та ін.] // Х.:НТМТ. - 2012. - 456 с.

2. Fluoroquinolone resistance: mechanisms, impact on bacteria, and role in evolutionary success [Electronic resource] / L. S. Redgrave et al. // Trends in microbiology. - 2014. - Vol. 22(8). - P. 438-445. Mode of access: http://www.cell.com/trends/microbiology/fulltext/S0966-842X(14)00089-4

3. Graham D. Y. Letter: bismuth, levofloxacin, amoxicillin, PPI quadruple therapy is not an effective first or second line regimen in the presence of levofloxacin resistance [Electronic resource] / D. Y. Graham, H. Lu // Alimentary pharmacology \& therapeutics. - 2015. - Vol. 41(11). - P. 1220-1221.Mode of access: http://onlinelibrary.wiley.com/doi/10.1111/apt.13177/full

4. Всемирная организация здравоохранения. Всемирный день здоровья 2011 года. Борьба с лекарственной устойчивостью //BO3, Женева.-2011. URL:http://www.who.int/mediacentre

5. Antibiotic resistance - the need for global solutions [Electronic resource] / R. Laxminarayan et al. // The Lancet infectious diseases. - 2013. - Vol. 13(12). - P. 1057-1098. - Mode of access: http://www.sciencedirect.com/science/article/pii/S1473309913703

6. Causes and timing of death in extremely premature infants from 2000 through 2011 [Electronic resource] / R. M. Patel et al. // New England Journal of Medicine. - 2015. - Vol. 372(4). - P. 331-340. - Mode of access: http://www.nejm.org/doi/full/10.1056/NEJMoa1403489

7. European survey on principles of prudent antibiotic prescribing teaching in undergraduate students / C. Pulcini, F. Wencker, N. Frimodt-Møller, W. V. Kern, D. Nathwani, J. Rodríguez-Baño, \& ESGAP Curriculum Working Group //Clinical Microbiology and Infection. - 2015. - T. 21. - №. 4. - C. 354-361.

8. Современные подходы к контролю и сдерживанию антибиотикорезистентности в мире / Кулмагамбетов И.Р., Сарсенбаева С.С., Рамазанова Ш.Х., Есимова Н.К.//nternational journal of appliedand fundamental research No 9, 2015, c. 54-59.

9. Health authorities worry that these superbugs will become unstoppable. By Teresa Carr January 19, 2017 . [Електронний ресурс]. - Режим доступу: http://www.consumerreports.org/overuse-ofantibiotics/dangerous-antibiotic-resistant-bacteria-spreading

10. Molecular mechanisms of antibiotic resistance [Electronic resource] / J. M. Blair et al. // Nature Reviews Microbiology. - 2015. - Vol. 13(1). - P. 42-51. - Mode of access: https://www.ars.usda.gov/alternativestoantibiotics/PDF/ publications/MolMechAntibiotResistNRM2014.pdf 
11. National Antimicrobial Resistance Surveillance Thailand (NARST). Antimicrobial Resistance 20002016 [Електронний ресурс]. - Режим доступу: http:/narst.dmsc.moph.go.th/data/AMR\%202000-2016.pdf

12. OIE Annual report on the use of antimicrobial agents in animals. Better understanding of the global situation. 2016 [Електронний pecypc]. - Режим доступу: http:/www.oie.int/fileadmin/Home/fr/Our_scientific_expertise/docs/pdf/AMR/Survey_on_monitoring_antimicrobial_agents_Dec2016.pdf

13. Глобальный план действий по борьбе с устойчивостью к противомикробным препаратам. // Шестьдесят девятая сессия Всемирной Ассамблеи Здравоохранения. Пункт 14.4 предварительной повестки дня (A69/24 Add.1. от 13 мая 2016 г.) / Всемирная организация здравоохранения. - Женева: BO3, 2016. - 12 с. - Режим доступа:http://apps.who.int/gb/ebwha/pdf_files/WHA69/A69_24Add1-ru.pdf.

14. Визначення чутливості мікроорганізмів до антибактеріальних препаратів: [методичні вказівки] / Наказ МОЗ України № 167 від 05.04.2007. - http://mozdocs.kiev.ua/view.php?id=6958

\section{ИЗУЧЕНИЕ БИОЛОГИЧЕСКИХ СВОЙСТВ ЭПИЗООТИЧЕСКИХ ШТАММОВ} SALMONELLA SPP.. / Л. Н. Выговская

Актуальность токсикоинфекиий, вызываемых SALMONELLA SPP., очень высокая во всем мире. Заболевание характеризуется различными клиническими проявлениями. Возможно бессимптомное носительство и тяжелье случаи септических форм. Распространение устойчивых к антимикробным препаратам атипичных вариантов значительно усложняет терапию и дифференциальную диагностику сальмонеллеза. В статье приведены результаты исследований биологических свойств (культурально-морфологических, ферментативних, патогенных, антибиотикорезистентности) штаммов SALMONELLA SPP, выделенных на территории Украины при проведении микробиологических исследований.

Ключевые слова: сальмонеллез, биологические свойства, антибиотикорезистентнисть, чувствительность.

\section{STUDY OF BIOLOGICAL PROPERTIES EPIZOOTIC STRAINS SALMONELLA SPP./} L. Vygovska

Introduction. Etiotropic therapy for salmonellosis consists in the use of derivatives of penicillin and fluoroquinolones. In the Department of Microbiological Research, the Ukrainian Laboratory of Quality and Safety of Agricultural Products studies of the biological properties of epizootic strains and the study of their antibiotic susceptibility.

The goal of the work. study of biological properties and sensitivity to antibiotics of epizootic strains of Salmonella spp. in $S$-, $R$-, L-forms.

Materials and methods. The biological properties of Salmonella spp were studied according to culture-morphological, enzymatic, antigenic properties, pathogenicity and antibiotic sensitivity to disodiphyseal method in accordance with EUCAST.

Results of research and discussion. According to the results of studies, there were isolated 59 strains of Salmonella spp. Strains in the R-and L-forms differed from the strains in the S-form with low levels of biological activity and loss of some properties. Salmonella spp. S-form showed resistance to most antibiotics. In R-, L-forms to penicillins, cephalosporins, aminoglycosides, and ftrochinolones there was an increase in sensitivity in S. cholerae suis, S.dublin strains; in S. typhimurium - a decrease in sensitivity. All cultures in the $R$-, L-forms significantly reduced the sensitivity to carbopenems. To macrolides and linzamides, changes in sensitivity were not recorded. The sensitivity of cultures to tetracyclines increased, with the exception of $S$. typhimurium in the R-form. Nitrofurans - marked a decrease in the sensitivity of S. ch.suis L-forms and increased in $S$. dublin L-forms. To azoles were marked reduction S. ch.suis in the R-form, other cultureswithout changes.

Conclusions and prospects for further research.Strains of Salmonella spp. in S-form had typical culturally-morphological, enzymatic and pathogenic properties, antigenic structure; in the $R$ - and L-forms 
differed from the strains in the S-form with low levels of biological activity and loss of some properties. Salmonella spp. exhibited resistance to most antibiotics from the studied groups; in the dissociation states there were some changes in the sensitivity of cultures to antibiotics. Further research will focus on determining the mechanisms of antibiotic resistance in the strains examined.

Key words: salmonella, biological properties, antibiotic resistance, sensitivity.

\section{REFERENCES}

1. Salmanov A.G., Marijevs'kyj V.F., Bojko V.V., Ioffe I.V. \& Taraban I.A. (2012) Antibioticsoresistance in hirurgies: [Antibiotics resistance in hirurgies]. Kh.: NTMT [in Ukrainian].

2. L. S. Redgrave et al. (2014) Fluoroquinolone resistance: mechanisms, impact on bacteria, and role in evolutionary success. Trends in microbiology. 22(8), 438-445. - Retrieved from: http://www.cell.com/trends/microbiology/fulltext/S0966-842X(14)00089-4 [in English].

3. Graham D. Y.\& Lu H (2015) Letter: bismuth, levofloxacin, amoxicillin, PPI quadruple therapy is not an effective first or second line regimen in the presence of levofloxacin resistance. Alimentary pharmacology \& therapeutics. 41(11), 1220-1221.- Retrieved from: http://onlinelibrary.wiley.com/doi/10.1111/apt.13177/full [in English].

4. Vsemirnaja organizacija zdravoohranenija. Vsemirnyj den' zdorov'ja 2011 goda. Bor'ba s lekarstvennoj ustojchivost'ju [World Health Organization. World Health Day 2011 Fighting drug resistance] (2011) who.int Retrieved from http://www.who.int/mediacentre [in Russian].

5. R. Laxminarayan et al. (2013) Antibiotic resistance - the need for global solutions. The Lancet infectious diseases. Vol. 13(12), 1057-1098. - Retrieved from: http://www.sciencedirect.com/science/article/pii/S1473309913703 [in English].

6. Ravi M. Patel, M.D., Sarah Kandefer, B.S., Michele C. Walsh, M.D., Edward F. Bell, M.D.,

Waldemar A. Carlo, M.D. et al. (2015) Causes and timing of death in extremely premature infants from 2000 through 2011. New England Journal of Medicine.Vol. 372(4), 331-340. Retrieved from:

http://www.nejm.org/doi/full/10.1056/NEJMoa1403489 [in English].

7. C. Pulcini, F. Wencker, N. Frimodt-Møller, W. V. Kern, D. Nathwani, J. Rodríguez-Baño, \& ESGAP Curriculum Working Group (2015) European survey on principles of prudent antibiotic prescribing teaching in undergraduate students. Clinical Microbiology and Infection., 21, 4, 354-361. [in English].

8. Kulmagambetov I.R., Sarsenbaeva S.S., Ramazanova Sh.H.\& Esimova N.K. (2015) Sovremennye podhody $\mathrm{k}$ kontrolju i sderzhivaniju antibiotikorezistentnosti $\mathrm{v}$ mire [Modern approaches to the control and containment of antibiotic resistance in the world].International Journal of Applied and Fundamental Research, 9, 54-59 [in Russian].

9. Health authorities worry that these superbugs will become unstoppable. By Teresa Carr January 19, 2017. Retrieved from: http://www.consumerreports.org/overuse-of-antibiotics/dangerous-antibiotic-resistantbacteria-spreading/ [in English].

10. Blair J. M. et al. (2015) Molecular mechanisms of antibiotic resistance. Nature Reviews Microbiology. 13(1), 42-51. - Retrieved from: https://www.ars.usda.gov/alternativestoantibiotics/PDF/publications/MolMechAntibiotResistNRM2014.pdf [in English].

11. National Antimicrobial Resistance Surveillance Thailand (NARST). Antimicrobial Resistance 2000-201. Retrieved from: http://narst.dmsc.moph.go.th/data/AMR\%202000-2016.pdf [in English].

12. OIE Annual report on the use of antimicrobial agents in animals. Better understanding of the global situation (2016) Retrieved from: http://www.oie.int/fileadmin/Home/fr/Our_scientific_expertise/docs/pdf/AMR/Survey_on_monitoring_antimicrobial_agents_Dec2016.pdf [in English].

13. Global'nyj plan dejstvij po bor'be s ustojchivost'ju k protivomikrobnym preparatam [The Global Action Plan to Combat Antimicrobial Resistance]. Geneva: WHO: who.int Retrieved from http://apps.who.int/gb/ebwha/pdf_files/WHA69/A69_24Add1-ru.pdf [in Russian].

14. Vyznachennja chutlyvosti mikroorganizmiv do antybakterial'nyh preparativ [Determination of the sensitivity of microorganisms to antibacterial drugs] (n.d) mozdocs.kiev.ua. Retrieved from http://mozdocs.kiev.ua/view.php?id=6958 [in Ukrainian]. 